\title{
Spatial arrangement of an RNA zipcode identifies mRNAs under post-transcriptional control
}

\author{
Vivek L. Patel, ${ }^{1}$ Somdeb Mitra, ${ }^{2}$ Richard Harris, ${ }^{2}$ Adina R. Buxbaum, ${ }^{1}$ Timothée Lionnet, ${ }^{1}$ \\ Michael Brenowitz, ${ }^{2}$ Mark Girvin, ${ }^{2}$ Matthew Levy, ${ }^{2}$ Steven C. Almo, ${ }^{2}$ Robert H. Singer, ${ }^{1}$ \\ and Jeffrey A. Chao ${ }^{1,3}$ \\ ${ }^{1}$ Department of Anatomy and Structural Biology, ${ }^{2}$ Department of Biochemistry, Albert Einstein College of Medicine, Bronx, \\ New York 10461, USA
}

\begin{abstract}
How RNA-binding proteins recognize specific sets of target mRNAs remains poorly understood because current approaches depend primarily on sequence information. In this study, we demonstrate that specific recognition of messenger RNAs (mRNAs) by RNA-binding proteins requires the correct spatial positioning of these sequences. We characterized both the cis-acting sequence elements and the spatial restraints that define the mode of RNA binding of the zipcode-binding protein 1 (ZBP1/IMP1/IGF2BP1) to the $\beta$-actin zipcode. The third and fourth KH (hnRNP K homology) domains of ZBP1 specifically recognize a bipartite RNA element comprised of a 5 ' element (CGGAC) followed by a variable $3^{\prime}$ element (C/A-CA-C/U) that must be appropriately spaced. Remarkably, the orientation of these elements is interchangeable within target transcripts bound by ZBP1. The spatial relationship of this consensus binding site identified conserved transcripts that were verified to associate with ZBP1 in vivo. The dendritic localization of one of these transcripts, spinophilin, was found to be dependent on both ZBP1 and the RNA elements recognized by ZBP1 KH34.
\end{abstract}

[Keywords: ZBP1; RNA-binding protein; KH domain; RNA localization]

Supplemental material is available for this article.

Received August 19, 2011; revised version accepted November 23, 2011.

The localization of messenger RNA (mRNA) to subcellular compartments is an evolutionarily conserved mechanism for spatially restricted synthesis of proteins required for polarized cellular functions. Asymmetric localization of specific RNAs is important for diverse processes such as mating type switching in Saccharomyces cerevisiae, embryonic development in Drosophila, and synaptic plasticity in neurons (Holt and Bullock 2009; Martin and Ephrussi 2009). The $\beta$-actin mRNA was one of earliest transcripts shown to localize to the leading edge of chicken embryo fibroblasts and to extending neuronal growth cones (Lawrence and Singer 1986; Zhang et al. 1999). The localization of $\beta$-actin mRNA in these polarized cells provides a model system for understanding the molecular mechanisms responsible for targeting and transport of mRNAs to distinct cytoplasmic compartments.

Sorting of the $\beta$-actin transcript requires a 54-nucleotide (nt) cis-acting zipcode within its $3^{\prime}$ untranslated region (UTR), which was shown to be necessary and sufficient for targeting reporter RNAs to the cellular periphery of

${ }^{3}$ Corresponding author.

E-mail jeffrey.chao@einstein.yu.edu.

Article is online at http://www.genesdev.org/cgi/doi/10.1101/gad.177428.111. fibroblasts, dendritic filopodia, and axonal growth cones (Kislauskis et al. 1994; Zhang et al. 2001; Eom et al. 2003). Mutation of the zipcode or treatment with antisense oligonucleotides directed against the zipcode leads to delocalization of $\beta$-actin mRNA, alteration of cell morphology, and decreased cell motility (Kislauskis et al. 1994; Shestakova et al. 2001; Zhang et al. 2001; Eom et al. 2003). Zipcode-binding protein 1 (ZBP1) is a trans-acting factor that specifically recognizes the $\beta$-actin zipcode and is important for proper localization and translational regulation of the $\beta$-actin mRNA (Ross et al. 1997; Farina et al. 2003; Huttelmaier et al. 2005; Chao et al. 2010). Knockdown of ZBP1 by siRNA was shown to impair cellular adhesion, motility, and invadopodia formation (Vikesaa et al. 2006).

ZBP1 is a member of a highly conserved family of RNAbinding proteins (RBPs) that have been shown to be involved in RNA localization and stability and in translational regulation of many mRNAs (Yaniv and Yisraeli 2002; Yisraeli 2005). All members share a characteristic arrangement of six canonical RNA-binding domains (RBDs), consisting of two RNA recognition motifs (RRMs) followed by four hnRNP K homology $(\mathrm{KH})$ domains. Despite the diverse array of ZBP1 family members under investi- 
gation, a coherent model for sequence-specific RNA recognition by these RBPs has remained elusive. A precise determination of their specificity has not been obtained because the contributions of the individual RBDs, which often recognize short sequences that can be degenerate, have not been thoroughly characterized (Auweter et al. 2006; Lunde et al. 2007). Thus far, only short RNA consensus sites have been identified for ZBP1 family members, which cannot fully describe the interaction of these multi-RBD proteins with RNA (Nielsen et al. 1999; Kwon et al. 2002; Farina et al. 2003; Munro et al. 2006; Hafner et al. 2010). Consequently, identification of the mRNA ligands for this family of RBPs using these sequence elements has proven challenging.

Within the last decade, several alternate approaches to determine the targets of RBPs that use microarrays (RIPChip [RNP immunoprecipitation microarray]) (Keene et al. 2006) and high-throughput sequencing (HTS-CLIP and CRAC) (Licatalosi et al. 2008; Granneman et al. 2009) have emerged. These system-level approaches have identified the post-transcriptional networks that are regulated by a number of RBPs and have led to the construction of alternative splicing maps that are able to predict whether or not an exon is included in a transcript based on the position of an RBP-binding site (Ule et al. 2006; Yeo et al. 2009; Zhang et al. 2010). These methodologies, however, are inherently noisy and would benefit from more complete consensus site determinations that use both sequence specificity and spatial restraints, which arise from the structural arrangement of the RBDs within the protein.

Here we present biochemical and structural characterization of the cis- and trans-acting factors required for ZBP1 recognition of the $\beta$-actin zipcode RNA. The two C-terminal $\mathrm{KH}$ domains of ZBP1 (KH3 and $\mathrm{KH} 4$ ) recognize a bipartite RNA sequence, with $\mathrm{KH} 4$ binding to the 5 ' element (CGGAC) and KH3 binding to the 3 ' element (C/A-CA-C/U). This consensus site was used to predict novel targets of ZBP1 and was found to reliably identify mRNA ligands that associate with ZBP1 in mouse embryonic neurons. The dendritic localization of one of these target transcripts, spinophilin (PPP1R9B), requires both the trans-acting factor ZBP1 and the cisacting RNA elements recognized by ZBP1 KH34.

\section{Results \\ Identification of the bipartite RNA element recognized by ZBP1 KH34}

The high-affinity RNA-binding site for ZBP1 resides within the first $28 \mathrm{nt}$ of the chicken $\beta$-actin 3' UTR. Previously, we identified a bipartite RNA element located within this region that was specifically recognized by the anti-parallel pseudo-dimer conformation of the third and fourth $\mathrm{KH}$ domains of ZBP1 (KH34) (Chao et al. 2010). The position of the bipartite element was confirmed by hydroxyl radical footprinting; however, the nucleotides responsible for sequence-specific recognition by ZBP1 KH34 within the two RNA elements had not been determined (Supplemental Fig. S1). In order to define the consensus RNAbinding site for ZBP1 KH34, we systematically mutated the bases of the nucleotides within the bipartite element and used a polyacrylamide gel electrophoretic mobility shift assay (EMSA) to measure the change in Gibbs free energy $\left(\Delta \Delta \mathrm{G}^{\circ}\right)$ of binding the mutant RNAs compared with the wild-type RNA sequence.

The thermodynamic contribution of each base within the $5^{\prime}$ recognition element (5RE) of the bipartite RNAbinding site (nucleotides 3-7; 5' -CGGAC-3') toward ZBP1 KH34 recognition was determined by measuring the change in RNA-binding affinity for all possible single-point mutations (15 total mutations). Almost all of the base substitutions resulted in decreases in RNA-binding affinity of greater than an order of magnitude $\left(\Delta \Delta \mathrm{G}^{\circ}>1.3 \mathrm{kcal} \mathrm{mol}^{-1}\right)$ (Fig. 1A,B). The only exception was the A6U mutation that decreased RNA-binding affinity by about threefold $\left(\Delta \Delta \mathrm{G}^{\circ}=0.6 \pm 0.2 \mathrm{kcal} \mathrm{mol}^{-1}\right)$. These results indicate that the $\mathrm{KH}$ domain of ZBP1 KH34 responsible for recognizing the $5 \mathrm{RE}$ of the bipartite element has stringent sequence specificity and does not tolerate alternate bases.
A.

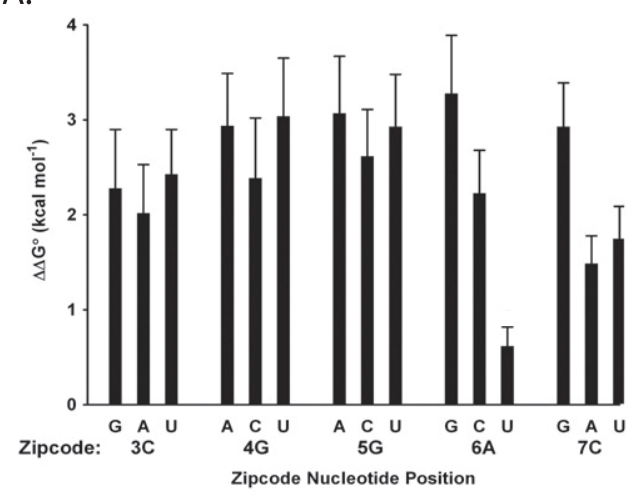

B.

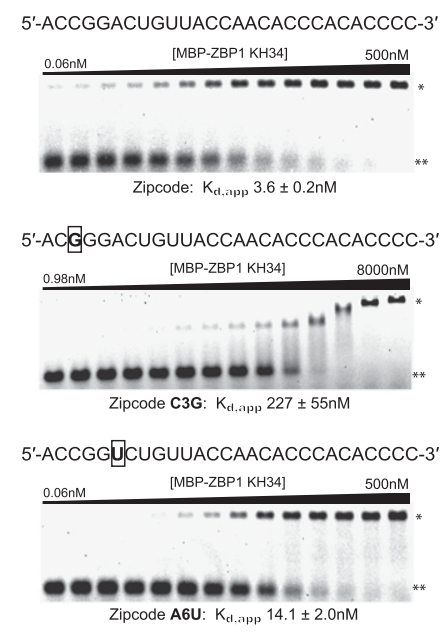

Figure 1. Sequence specificity of the 5RE. (A) Change in free energy of binding of point mutants as measured by fitting a fraction of RNA bound in EMSA to the Hill equation to measure the binding constant $\left[\mathrm{K}_{\mathrm{d}, \mathrm{app}}\right]$. Error bars represent standard deviations of at least three replicates. (B) Representative EMSA experiments for wild-type zipcode RNA, C3G mutant RNA, and A6U mutant RNA. The filled triangle represents a 1:1 serial dilution of ZBP1 KH34. The ZBP1 KH34-RNA complex $\left({ }^{\star}\right)$ and free RNA $\left({ }^{* *}\right)$ are labeled. 
Determination of the consensus sequence for the $3^{\prime}$ recognition element (3RE) of the bipartite RNA-binding site was complicated by the preponderance of cytidines in this region (nucleotides 19-28; 5'-CCCACACCCC-3'). Since single $\mathrm{KH}$ domains recognize short stretches $(\sim 4$ $\mathrm{nt}$ ) of RNA, and the precise distance between the 5RE and the $3 \mathrm{RE}$ is not evolutionarily conserved in $\beta$-actin $3^{\prime}$ UTRs, the sequence degeneracy in this region prevented the use of single-point mutations to determine the contribution to RNA-binding affinity of individual nucleotide positions. In order to determine whether an adenosine within the $3 \mathrm{RE}$ was required for $\mathrm{ZBP} 1 \mathrm{KH} 34$ recognition, both positions within this region were mutated to cytidine (nucleotides 19-28; 5'-CCC드CCCC-3'). This mutant RNA had an approximately threefold weaker RNA-binding affinity $\left(\Delta \Delta \mathrm{G}^{\circ}=0.7 \pm 0.1 \mathrm{kcal} \mathrm{mol}^{-1}\right)$, which indicated that while an adenosine was preferred within the $3 \mathrm{RE}$, there was not a strong sequence specificity, as observed in the 5RE (Supplemental Fig. S2).

In order to better define the sequence requirements for recognition of the $3 \mathrm{RE}$ by $\mathrm{ZBP} 1 \mathrm{KH} 34$, an in vitro selection for binding to ZBP1 KH34 was performed using an RNA library where nucleotide positions 1-15 were fixed as wild type and positions 16-28 were randomized (5'-ACCGGACTGTTACCA-N13-3'). After nine rounds of selection and amplification, the RNA population was determined to bind to ZBP1 KH34 with a 15-fold higher affinity than the initial randomized RNA library (Fig. 2B). This approach identified three families of RNAs $184 \%$ of all sequenced RNAs) that each contained 4-nt motifs (5'CCAC-3' ' 5' -CCAU-3', and 5' -ACAU-3') and were highly enriched compared with the initial population of RNAs (Fig. 2A). Individual clones from the ninth round of selection that represented the three RNA families were recognized by ZBP1 KH34 with similar RNA-binding affinities, indicating that some variability could be tolerated in the identity of the nucleotides that flank the core CA dinucleotide (Fig. 2B). Based on this SELEX experiment, we define the consensus binding site of the $3 \mathrm{RE}$ as $5^{\prime}-(\mathrm{C} / \mathrm{A})-\mathrm{CA}-(\mathrm{C} / \mathrm{U})-3^{\prime}$.

\section{ZBP1 KH3 and KH4 are responsible for $3^{\prime}$ and $5^{\prime}$ RNA element recognition}

Crystallization of ZBP1 KH34 or IMP1 KH34, the human ortholog of ZBP1, in complex with either the 5RE or 3RE has thus far proven to be difficult due to the low solubility of the RNA-protein complexes $(<50 \mu \mathrm{M})$. This concentration of the complexes, however, is sufficient for performing nuclear magnetic resonance (NMR) experiments. Free IMP1 KH34 yielded well-resolved NMR spectra that allowed backbone $\left({ }^{13} \mathrm{C},{ }^{15} \mathrm{~N}\right.$, and $\left.{ }^{1} \mathrm{H}\right)$ assignments to be unambiguously made for $78 \%$ of the protein (Supplemental Fig. S3). The majority of the unassigned residues were clustered around the solvent-accessible GXXG loops of KH3 (I421-K429) and KH4 (G504-A518) that have previously been shown to be dynamic in other unbound KH domain structures (Musco et al. 1997).

In order to determine the orientation of KH34 to the RNA, ${ }^{15} \mathrm{~N}-\mathrm{HSQC}$ spectra were collected of KH34 in com-
A.

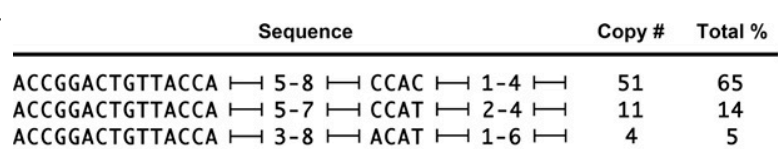

B.

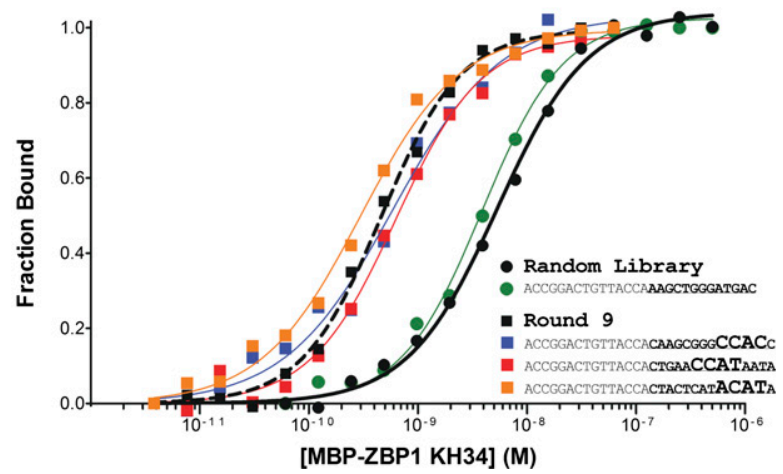

Figure 2. Sequence specificity of the 3RE. (A) The family of sequence motifs recovered after nine rounds of selection is shown. The range of nucleotide spacing between the nonrandomized zipcode residues and the selected motifs is indicated for each sequence. Copy numbers for each motif from a pool of 78 sequenced clones are listed. $(B)$ Quantification and fit to the Hill equation of EMSA results for ZBP1 KH34 binding to the random $3^{\prime}$ zipcode library (solid black line), a representative clone from the library pool (green line), the round 9 selected population (dashed black line), and representative clones from the round 9 population containing the three most commonly selected sequence motifs (red, blue, and orange lines).

plex with short RNA sequences containing either the 5RE $\left(5^{\prime}\right.$-CCGGACU-3') or the 3RE (5'-CACACCC-3') (Fig. 3A). The chemical shifts of the amide resonances that were altered upon binding to the 3RE RNA were located within the canonical RNA-binding surface of KH3 (Fig. 3B). This assignment is consistent with homology modeling of IMP1 KH3 with hnRNP K KH3, PCBP2 KH1, and Nova$2 \mathrm{KH} 3$, all of which specifically recognize a cytosine by base-specific hydrogen bonds made by an arginine residue located within the third $\beta$ strand of their $\mathrm{KH}$ domains (Lewis et al. 2000; Backe et al. 2005; Du et al. 2007, 2008). Addition of the 5RE RNA to KH34 resulted in the disappearance of many amide resonances within the canonical RNA-binding surface of $\mathrm{KH} 4$ as well as smaller chemical shift differences that were located within KH3 (Fig. 3B). The chemical shift changes that were observed within KH3 upon binding the 5RE RNA likely result from the excess RNA used in the NMR experiment coupled with the weaker sequence specificity of the KH3 domain. Taken as a whole, these experiments identify the RNAbinding specificities of the $\mathrm{KH} 3$ and $\mathrm{KH} 4$ domains and also confirm that each $\mathrm{KH}$ domain interacts with its RNA target via its canonical RNA-binding surface and not through an alternate RNA-binding mode.

\section{$Z B P 1$ recognizes its consensus $R N A$ elements} in both linear arrangements

Modeling of the 5RE and 3RE RNAs bound to KH3 and $\mathrm{KH} 4$ indicates that the intervening RNA nucleotides 
A.

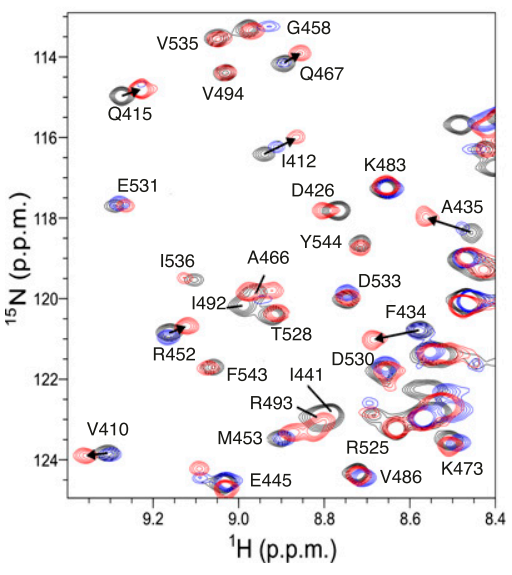

B.

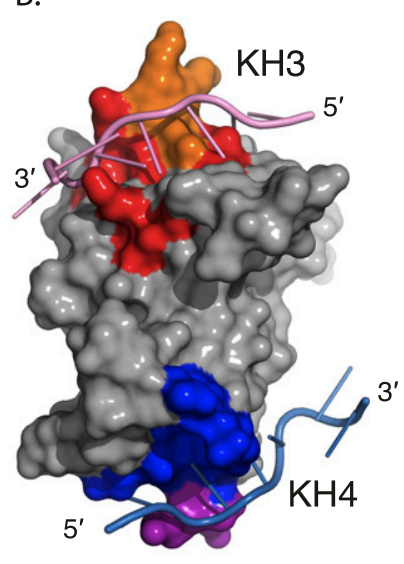

Figure 3. RNA sequence elements recognized by the $\mathrm{KH}$ domains of ZBP1 KH34. (A) ${ }^{15} \mathrm{~N}-\mathrm{HSQC}$ spectra of KH34 (black) in complex with RNAs containing either the 5RE (blue) or the 3RE (red). $(B)$ Location of chemical shifts of amide resonances altered upon binding to the 3RE RNA (red) and 5RE (blue). Amino acids whose amide resonances were not assigned are indicated in orange (KH3) and violet (KH4). between the REs must loop in the direction of the residues that connect KH3 and KH4. Previously, we showed that mutation of these amino acids (F478-K486) to the residues that link $\mathrm{ZBP} 1 \mathrm{KH} 1$ and $\mathrm{KH} 2$ resulted in a large decrease in RNA-binding affinity (Chao et al. 2010). However, it could not be determined whether this effect was due to disruption of direct RNA-protein interactions or destabilization of the anti-parallel pseudo-dimer conformation. In order to further characterize the role of the KH34 linker in RNA recognition, a mutant protein was generated that had both phenylalanines (F478 and F479) in the linker mutated to alanine. The ZBP1 KH34 F478A,F479A mutant protein was unable to bind the first $28 \mathrm{nt}$ of the zipcode with high affinity $\left(\mathrm{K}_{\mathrm{d}, \text { app. }}>500 \mathrm{nM}\right.$ ) (Supplemental Fig. S4A), as was previously observed when all of the amino acids in the linker were mutated (Chao et al. 2010). Thermal denaturation of ZBP1 KH34 F478A,F479A monitored by circular dichroism revealed that the double mutation had a $\mathrm{T}_{M}$ of $50.1{ }^{\circ} \mathrm{C} \pm 0.5^{\circ} \mathrm{C}$, which is lower than the wild-type protein $\left(\mathrm{T}_{\mathrm{M}}, 56.3^{\circ} \mathrm{C} \pm 0.3^{\circ} \mathrm{C}\right)$ and indicates destabilization of the KH34 pseudo-dimer conformation (Supplemental Fig. S4B). These results suggest that hydrophobic interactions made by F478 and F479 within the pseudo-dimer interface are critical for maintaining the precise orientation of the $\mathrm{KH} 3$ and $\mathrm{KH} 4$ domains required for RNA recognition.

To assess the contribution of the residues that connect $\mathrm{KH} 3$ and $\mathrm{KH} 4$ toward discriminating RNA ligands, we swapped the positions of the $5 \mathrm{RE}$ and the $3 \mathrm{RE}$ along the transcript such that the connecting nucleotide loop was extruded opposite the KH34 linker (Fig. 4A). Notably, this mode of RNA binding does not alter the polarity of the REs to the KH domain RNA-binding surfaces. ZBP1 KH34 was able to recognize the 5RE-3RE-swapped RNA with an affinity similar to that of the actin-like arrangement of the REs $\left(\Delta \Delta \mathrm{G}^{\circ} 0.25 \pm 0.06 \mathrm{kcal} \mathrm{mol}^{-1}\right)$ (Fig. 4B). Taken together, these results implicate the KH34 interdomain linker in stabilizing the ZBP1 RNA-binding platform without making direct interactions with the RNA. In contrast to ZBP1 KH34, the third and fourth RRMs of the polypyrimidine tract-binding protein are connected by a long, flexible, polar amino acid-containing linker that has been shown by NMR spectroscopy to directly contact looped segments of exon RNA flanked by RRM-bound pyrimidine tracts (Lamichhane et al. 2010). The absence of interactions between the KH34 linker and looped nucleotides suggests that ZBP1 may recognize cellular mRNAs containing both linear arrangements of the REs along a transcript (Fig. 4C). Further experiments will be required to

A. Zipcode: 5'-ACCGGACUGUUACCAACACCCACACCCC-3'
5'↔3' Swap: 5'-ACACACCCGUUACCAACACCCCGGACUC-3'

B. \begin{tabular}{lll}
$0.12 \mathrm{nM}$ & {$[\mathrm{MBP}-\mathrm{ZBP} 1 \mathrm{KH} 34]$} & $1000 \mathrm{nM}$ \\
\hline
\end{tabular}

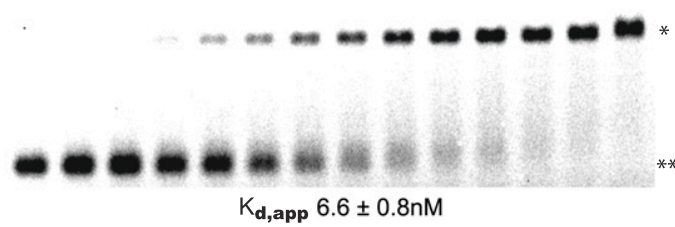

C.
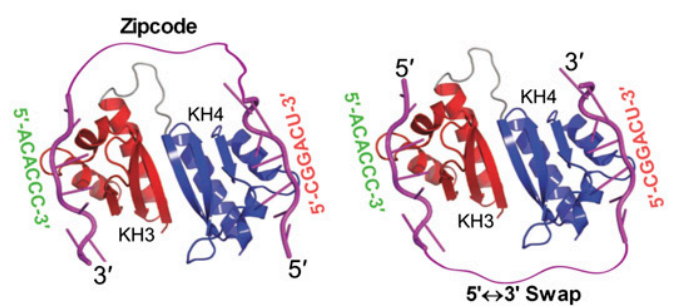

Figure 4. ZBP1 KH34 is capable of inducing bidirectional RNA looping. (A) Sequence of RNA in which the 5RE and 3RE were swapped. (B) Representative EMSA result for ZBP1 KH34 binding to RNA with the 5RE and 3RE swapped. The filled triangle represents a 1:1 serial dilution of ZBP1 KH34. The ZBP1 KH34-RNA complex $\left({ }^{\star}\right)$ and free RNA $\left(^{\star \star}\right)$ are labeled. $(C)$ Model of bidirectional RNA looping to facilitate simultaneous contact of both consensus RNA elements with the RNAbinding surfaces of KH3 and KH4. Polarity of the RNA elements to their respective $\mathrm{KH}$ domains is conserved in both models. 
clarify the consequences of altering the direction of looped nucleotides with respect to the KH34 linker for nucleating the assembly of higher-order RNA-protein complexes in vivo.

\section{Consensus RNA REs identify conserved mRNA ligands of $Z B P 1$}

To identify potential mRNA ligands of ZBP1, we queried the 3' UTRs of human and mouse transcripts for the bipartite RE bound by ZBP1 KH34 in both linear arrangements (Fig. 5A). The minimum spacing between these two elements was set to $10 \mathrm{nt}$ because shorter spacing had previously been shown to result in an almost 10-fold reduction in RNA-binding affinity (Chao et al. 2010). This dramatic loss in affinity is due to the inability of $\mathrm{KH} 3$ and KH4 to simultaneously bind the 5RE and 3RE when the spacing between the RNA sequences is too short to allow looping of the RNA between the binding sites. Comparison of the position of the 5RE and 3RE in mammalian $\beta$-actin mRNA 3' UTRs determined that the elements could be spaced at least $20 \mathrm{nt}$ apart; therefore, the affinity of ZBP1 KH34 for RNAs that had the REs separated by 25 and $30 \mathrm{nt}$ was measured. In contrast to what was found for the lower spacing limit, a more gradual reduction in RNA affinity was measured as the length between the $5 \mathrm{RE}$ and $3 \mathrm{RE}$ was increased to $25 \mathrm{nt}$ ( $\sim 2.5$-fold) and $30 \mathrm{nt}$ (about eightfold) (Supplemental Fig. S5A,B). Based on these measurements, an upper limit of $25 \mathrm{nt}$ was used for prediction of ZBP1 KH34 targets.

Our query identified 818 human and 613 mouse mRNA 3 ' UTRs containing the REs in the actin-like orientation. In order to enrich for bona fide ZBP1 target mRNAs, the overlap of these two lists was used to identify 67 genes that had the REs evolutionarily conserved (Fig. 5A). Similarly, we identified 796 human and 597 mouse mRNA 3' UTRs containing the REs in the $5^{\prime}-3^{\prime}$-swapped orientation, with
61 genes demonstrating evolutionary conservation in the swapped arrangement. In total, there were 114 unique mRNA targets that had the REs conserved in their 3' UTRs (Supplemental Table S1).

We used the curated Ingenuity Pathways Analysis (IPA) database to explore the functional relationship between proteins encoded by the 114 candidate mRNA targets of ZBP1. We probed for the most significantly enriched functions and disease associations in the 67 conserved RNA ligands with actin-like orientation of the KH34 REs and the 61 genes with 5'-3'-swapped arrangement of the REs. Interestingly, the gene ontology analysis revealed marked enrichment of the RNAs implicated in morphological and developmental functions in both RE arrangements, consistent with the primarily embryonic expression of ZBP1 (Fig. 5B,C; Nielsen et al. 1999; Shimogori et al. 2010). The functional networks that were enriched are consistent with published reports of cellular and global developmental defects observed with loss of ZBP1 function, such as failure of neurite outgrowth in response to neurotrophic stimulation (Eom et al. 2003) and systemic organ hypoplasia (Hansen et al. 2004). These observations suggest that defective post-transcriptional regulation of ZBP1 KH34 RNA ligands may be the mechanistic basis for these phenotypes.

To experimentally verify that the conserved REcontaining RNAs are bound by ZBP1 KH34 in vivo, we immunoprecipitated endogenous ZBP1 from mouse embryonic brain extract and performed quantitative RT-PCR (qRT-PCR) to detect mRNAs that associate with ZBP1. Gene-specific primers were used to probe for 25 mRNAs representative of the breadth of our original query. For 24 of the 25 genes that were tested, specific PCR products could be detected in both ZBP1 and IgG control pulldowns. A significant enrichment of predicted ZBP1 target mRNAs was observed over that of three nontarget mRNAs that do not contain KH34 REs ( $\beta$-2-microglobulin [B2M],

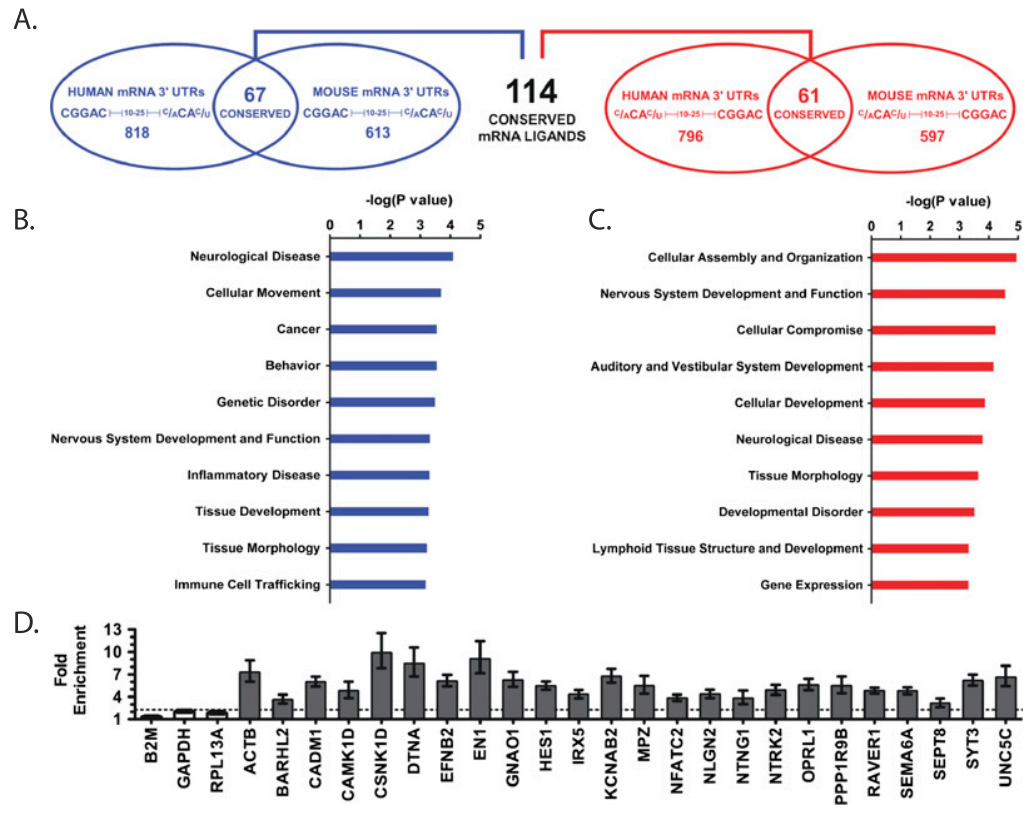

Figure 5. Consensus sequence for ZBP1 KH34 binding identifies novel mRNA ligands of ZBP1. (A) Human and mouse mRNA 3' UTRs containing the ZBP1 KH34-binding consensus sequence. $(B, C)$ Gene ontology analysis of conserved mRNA ligands containing the REs in the actin-like $(B)$ and $5^{\prime}-3^{\prime}-$ swapped $(C)$ orientation. $(D)$ Enrichment of ZBP1 KH34 target mRNAs in ZBP1 immunoprecipitation compared with IgG control. Negative controls (B2M, GAPDH, and RPL13A) that do not contain the REs in their 3' UTRs (open rectangle) and ZBP1 KH34 target mRNAs (filled rectangle) are shown. Error bars represent the SEM of at least two replicates using independent RIP experiments from littermate embryos. 
glyceraldehyde 3-phosphate dehydrogenase [GAPDH], and large ribosomal protein 13A [RPL13A]) in ZBP1 pull-downs as compared with IgG control (Fig. 5D). Furthermore, 17 of the 24 predicted ZBP1 target mRNAs were enriched by greater than fourfold in ZBP1 pull-downs. The ZBP1 immunoprecipitation experiments demonstrate that combining the sequence specificity of the 5RE and 3RE with the spatial arrangement of these RNA elements enables reliable prediction of RNAs bound by ZBP1 in vivo.

In order to gain insight into ZBP1's regulation of these mRNAs, total mRNA was isolated from embryonic brains of wild-type and ZBP1 knockout (KO) mice, and the transcript abundance of the 25 representative mRNAs was measured by qRT-PCR. Interestingly, we did not find a significant change in the steady-state mRNA levels of any of these transcripts, which suggests that ZBP1 does not regulate the stability of these mRNAs (Supplemental Fig. S6). Future research will be required to determine what effect ZBP1's interaction with these transcripts has on their post-transcriptional regulation.

\section{Dendritic localization of spinophilin $m R N A$ is ZBP1-dependent}

In order to confirm the functional consequence of the interaction between ZBP1 and its predicted target mRNAs that was observed in vivo, we investigated the dendritic localization of spinophilin (PPP1R9B) mRNA in developing hippocampal neurons using fluorescence in situ hybridization (FISH). Because ZBP1 has a well-established role in localization of the $\beta$-actin mRNA in developing neurites (Zhang et al. 2001; Eom et al. 2003; Tiruchinapalli et al. 2003; Yao et al. 2006; Perycz et al. 2011) and spinophilin mRNA has been shown to be localized in the dendrites of cultured hippocampal neurons and the dendritic lamina of the hippocampal CA1 region, we postulated that ZBP1 may play a role in its dendritic targeting (Zhong et al. 2006).

To determine whether the bipartite RE was necessary for the dendritic localization of the spinophilin mRNA, we used lentiviral gene transfer to express GFP reporter mRNAs that contained the spinophilin 3' UTR with and without the bipartite ZBP1 KH34 RE in hippocampal neurons. Since the spinophilin 3' UTR contains two copies of the ZBP1 KH34-binding site (nucleotide positions 19-42 and 1493-1523), both of these RNA sequences were deleted from the reporter construct (Supplemental Table S2). We quantified the localization of reporter mRNAs by FISH using fluorescently labeled antisense probes to the GFPcoding sequence (Fig. 6A). The GFP-spinophilin 3' UTR $\triangle \mathrm{KH} 34$ RE reporter RNA demonstrated a significant decrease in dendritic localization, as measured by a reduction in the average mRNA distance from the cell body (13.7 \pm $2.1 \mu \mathrm{m})$, as compared with the wild-type reporter $(28.3 \pm$ $4.9 \mu \mathrm{m} ; P<0.005$ ) (Fig 6B).

In order to further characterize the role of $\mathrm{ZBP} 1$ in the transport of spinophilin mRNA, we quantified the localization of endogenous spinophilin transcripts in developing hippocampal neurons from both wild-type and ZBP1$\mathrm{KO}$ mice. Loss of ZBP1 does not cause global defects in
A.

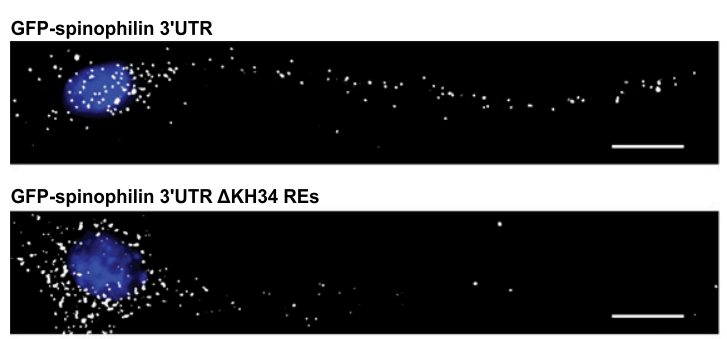

B.
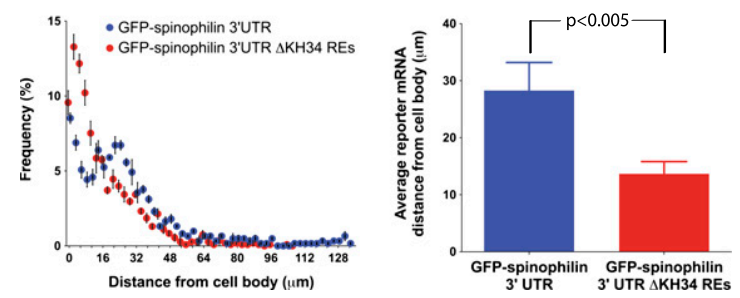

Figure 6. The ZBP1 KH34 REs are required for distal dendritic RNA transport. (A) FISH analysis of GFP-spinophilin 3' UTR and GFP-spinophilin 3' UTR $\triangle \mathrm{KH} 34 \mathrm{RE}$ reporter mRNAs in cultured hippocampal neurons. DAPI (blue) was used to demarcate the nucleus. Bars, $10 \mu \mathrm{m}$. (B) Distribution (left) and average (right) distance (in microns) of reporter mRNAs from the neuron cell body. Error bars represent the SEM; $P<0.005$.

dendritic mRNA localization as measured by FISH using oligo(dT) probes to detect all poly(A) mRNA in dendrites of cultured hippocampal neurons $(P>0.6)$ (Supplemental Fig. S7). However, the localization of spinophilin mRNA in dendrites of ZBP1-KO mice $(0.05 \pm 0.01$ mRNAs per micron) was diminished over twofold relative to wild type $(0.13 \pm 0.02$ mRNAs per micron; $P<0.0001)$ (Fig. 7A,B). This reduction in spinophilin mRNAs in dendrites was not due to altered spinophilin mRNA expression, as both wild-type and ZBP1-KO neurons have similar amounts of total spinophilin mRNA (Supplemental Fig. S6). Interestingly, despite the reduced quantity of localized transcripts, the average distance from the cell body of spinophilin mRNAs in ZBP1-KO neurons was nearly identical to wild type (Fig. 7C), indicating additional factors may facilitate distal spinophilin mRNA transport in neurons lacking ZBP1.

\section{Discussion}

Here we elucidate the cis- and trans-acting components of a conserved mechanism for translating RNA sequence information into spatial regulation of mRNAs in developing cells. Combined structural and biochemical studies reveal the RNA elements required for specific recognition of the $\beta$-actin zipcode by the third and fourth $\mathrm{KH}$ domains of ZBP1. These RNA elements recognized by ZBP1 KH34 in vitro are capable of identifying RNA ligands that associate with ZBP1 in vivo. Using high-resolution FISH, we determined that both $\mathrm{ZBP} 1$ and the bipartite RE bound by ZBP1 KH34 are required for the dendritic localization of spinophilin mRNA, a newly identified target of ZBP1. In summary, we revealed here the evolutionarily conserved 
A.

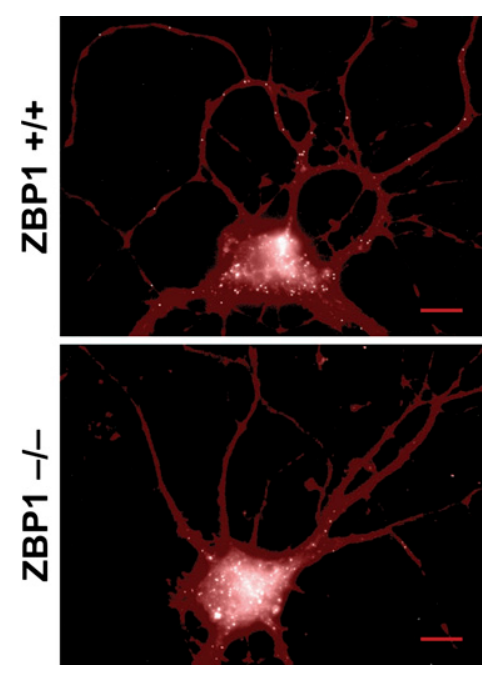

B.

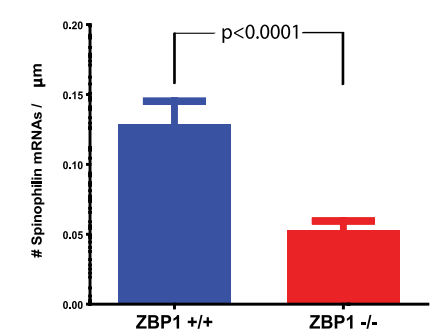

C.

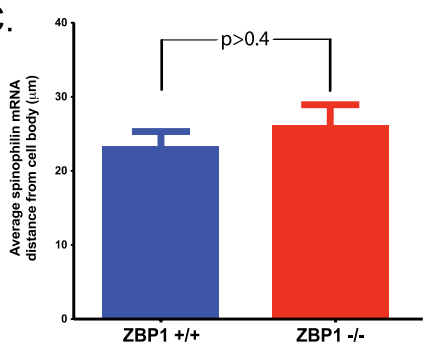

Figure 7. Dendritic localization of spinophilin mRNA is disrupted in ZBP1-KO mice. (A) FISH analysis of spinophilin transcripts in cultured hippocampal neurons of wild-type and ZBP1-KO mice. Cell-permeable CMAC dye (red) was used to demarcate cell boundaries. Bars, $10 \mu \mathrm{m} .(B)$ Average number of spinophilin transcripts in dendrites detected by FISH in developing hippocampal neurons from ZBP1 wild-type and knockout mice; $P<0.0001$. Quantity of mRNA detected in dendrites was normalized to dendrite length in microns. $(C)$ Average distance (in microns) of spinophilin transcripts from the neuron cell body. Error bars in $B$ and $C$ represent the SEM; $P>0.4$.
RNA sequence elements recognized by ZBP1 KH34 that mark transcripts for participation in ZBP1-operated posttranscriptional regulatory networks.

Functionally essential RNA REs might be expected to evolve under pressure to optimally facilitate biological processes, which may drive nonrandom distribution of these sequences in UTRs. The probability of random discovery of the $5 \mathrm{RE}$ and $3 \mathrm{RE}$ is one per $1024 \mathrm{nt}$ and 64 $\mathrm{nt}$, respectively. The incidence of both REs (in actin-like and swapped orientations) at the appropriate distance (10$25 \mathrm{nt})$ for ZBP1 KH34 binding is calculated to be one per 4096 nt. The University of California at Santa Cruz (UCSC) 3' UTR database that we queried contains $\sim 17,500$ human and 15,250 mouse 3' UTRs with average lengths of $1200 \mathrm{nt}$ and $900 \mathrm{nt}$, respectively. Based on the random probability, we anticipated that 5250 human and 3400 mouse gene $3^{\prime}$ UTRs, respectively, would contain the full motif. Interestingly, we found the actual rate of tandem 5RE and 3RE discovery to be approximately threefold less in both human and mouse transcriptomes (Fig. 5A). In contrast, the rate of discovery of the 5RE and 3RE in 5' UTRs was similar to that anticipated by chance. A gene ontology analysis of conserved mRNAs containing the REs in the 5' UTR also did not enrich genes implicated in functions similar to those evident in the 3' UTR. Taken together, these data support the hypothesis that evolutionary pressures preserve a nonrandom distribution of the quantity and location of functional cis-regulatory elements in $3^{\prime}$ UTRs.

Individual RBPs are often implicated in coordinating hundreds of functionally related mRNA targets by sequence-specific association with cis REs (Keene and Tenenbaum 2002). The ZBP1 KH34 REs identify similar numbers of potential mRNA ligands: $\sim 600-800$ transcripts in actin-like and swapped arrangements (Fig. 5A). A fraction of these ligands are evolutionarily conserved. Multiple developmental relationships are apparent in the conserved mRNA ligands of ZBP1 (Fig. 5B,C), coincident with the mid-late embryonic expression of ZBP1 (Nielsen et al.
1999; Shimogori et al. 2010). Both linear arrangements of the 5RE and 3RE enrich for genes affecting the development and potential dysfunction of the nervous system, congruous with the distribution of ZBP1 within maturing neurites and diminished outgrowth upon ZBP1 depletion (Eom et al. 2003). The functional relationships that were revealed suggest that regulation of mRNAs by ZBP1 may sort transcripts participating in related developmental networks for spatially and temporally coordinated regulation.

Two previous genome-wide studies used RIP-Chip and PAR-CLIP to identify putative ZBP1 consensus REs. While both of these studies used exogenous Flag-tagged ZBP1 overexpressed in HEK293 cells, they did not define similar RNA elements as being important for ZBP1 recognition, highlighting the inherent noise in these approaches. In the RIP-Chip experiment, ZBP1 targets were found to be enriched for a $5^{\prime}$-CCYHHCC-3' motif $(\mathrm{Y}=\mathrm{C}, \mathrm{U}$ and $\mathrm{H}=$ $A, C, U)$, while the PAR-CLIP experiment concluded that the ZBP1 consensus binding site was $5^{\prime}$-CAUH-3' and that $30 \%$ of targets contained a second copy of this motif within 3-5 nt (Jonson et al. 2007; Hafner et al. 2010) Interestingly, these consensus sites differ in both the identity of the nucleotides and the spacing between the RNA elements that we determined for recognition by the ZBP1 KH34 domain. These alternate RNA elements may represent the binding site for one of the other four RBDs of ZBP1 (RRM1, RRM2, KH1, or KH2). While the approach we took is limited to identifying only mRNA targets that require $\mathrm{ZBP} 1 \mathrm{KH} 34$ for recognition, care must be taken not to overinterpret genome-wide sequence information because conclusions must also be consistent with the physical restraints imposed by the structure of the protein. Further research will be necessary to determine the identity of all mRNAs regulated by the ZBP1 family of RBPs.

Post-transcriptional regulation requires the orchestrated assembly of distinct macromolecular RNA-protein com- 
plexes in order to differentially control the fate of transcripts within the cell. While the crux of sequence-specific RNA recognition is the interaction between individual RBDs and the nucleotide sequences that they recognize, these domains function within a larger context. Consequently, the consensus binding site for a single RBD may not be sufficient to fully explain how the full-length RBP binds to and regulates its mRNA targets. It has become increasingly clear that knowledge of the precise structural arrangement of these domains is required for understanding how an RBP discriminates between transcripts. Recent studies of the tandem RRMs (RRM12) of U2AF64 demonstrate that the dynamic equilibrium between two distinct conformations allows it to selectively recognize highaffinity polypyrimidine tracts and thereby modulate splicing (Mackereth et al. 2011). The development of structural techniques-like small-angle X-ray scattering-that provide insight into the shape and flexibility of macromolecular assemblies, coupled with advances in high-throughput RNA-binding site identification, will facilitate the determination of more complicated RNA-binding specificities (Ray et al. 2009; Kim et al. 2011). Post-transcriptional regulation is accomplished by the synergistic interaction of multiple RBPs along a transcript. Ultimately, understanding the RNA sequence and spatial restraints that determine how these macromolecular complexes assemble will be the focus of future investigation.

\section{Materials and methods}

\section{Protein preparation}

ZBP1 KH34 (residues 404-561) and ZBP1 KH34 F478A-F479A were expressed and purified as previously described (Chao et al. 2010). IMP1 KH34 (residues 404-566) was cloned by PCR into pET22HT as a C-terminal $\mathrm{His}_{6}$ tag. Uniform ${ }^{15} \mathrm{~N}$ - and ${ }^{2} \mathrm{H} /{ }^{13} \mathrm{C} /$ ${ }^{15} \mathrm{~N}$-labeled recombinant IMP1 $\mathrm{KH} 34 \mathrm{His}_{6}$ was expressed in Escherichia coli Rosetta2 grown in Spectra $9\left[{ }^{15} \mathrm{~N}, 98 \%\right]$ medium (Cambridge Isotope Laboratories) or M63 minimal medium with $98 \%{ }^{2} \mathrm{H}_{2} \mathrm{O}, 0.5 \mathrm{~g} \mathrm{~L}^{-1}\left({ }^{15} \mathrm{NH}_{4}\right)_{2} \mathrm{SO}_{4}$ and $2 \mathrm{~g} \mathrm{~L}^{-1}{ }^{13} \mathrm{C}_{6}$-glucose, respectively. Recombinant protein was induced and purified using conditions identical to those described for unlabeled protein. For NMR studies, a sample of $50 \mu \mathrm{M}^{15} \mathrm{~N}$-labeled IMP1 KH34 $\mathrm{His}_{6}$ in $10 \mathrm{mM}$ MES buffer (pH 6.5), $100 \mathrm{mM} \mathrm{NaCl}$, and $\mathrm{H}_{2} \mathrm{O} / \mathrm{D}_{2} \mathrm{O}(9: 1)$, and a sample of $350 \mu \mathrm{M}^{2} \mathrm{H} /{ }^{13} \mathrm{C} /{ }^{15} \mathrm{~N}$-labeled IMP1 KH34 $\mathrm{His}_{6}$ in $25 \mathrm{mM}$ Tris buffer (pH 7.2), $300 \mathrm{mM} \mathrm{NaCl}$, and $\mathrm{H}_{2} \mathrm{O} / \mathrm{D}_{2} \mathrm{O}(9: 1)$ were prepared.

\section{EMSA}

Complexes of recombinant ZBP1 KH34 constructs with zipcode and zipcode mutant RNA fragments were monitored by an EMSA as previously described (Chao et al. 2010). RNAs (100 $\mathrm{pM}$ ) were equilibrated with a twofold serial dilution of recombinant proteins in a buffer containing $10 \mathrm{mM}$ Tris (pH 7.2), 100 $\mathrm{mM} \mathrm{NaCl}, 0.1 \mathrm{mM}$ EDTA, $0.01 \mathrm{mg} \mathrm{mL}^{-1}$ tRNA, $5 \mu \mathrm{gL}^{-1}$ heparin, and $0.01 \%$ IGEPAL CA630 for $\sim 3 \mathrm{~h}$ in order to ensure that the binding reaction reached equilibrium. Protein-RNA complexes were resolved from unbound RNA by native polyacrylamide gel electrophoresis $(5 \%[\mathrm{w} / \mathrm{v}]$ 29:1 acrylamide/bisacrylamide, $0.5 \times \mathrm{TBE})$ run at $80 \mathrm{~V}$ at $4^{\circ} \mathrm{C}$. Gels were scanned using a fluorescent gel imager (Typhoon 9400, GE Healthcare) with 488-nm excitation and a 520 BP 40 filter. The sequences of the
RNAs used in these experiments are in the Supplemental Material.

\section{RNA selection using a random 3' zipcode[1-28] library}

An antisense $3^{\prime}$-random zipcode[1-28] library with the sequence 5'-AAGCTTCGTCAAGTCTGCAGTGAA-(N13)-TGGTAACAG TCCGGTTCGTAGATGTGGATCCATTCCC-3' was prepared by chemical synthesis (Integrated DNA Technologies). Thirteen nucleotides at the $3^{\prime}$ end of the 28-nt zipcode, positions 16-28, were randomized to $25 \% \mathrm{~A}, 25 \% \mathrm{~T}, 25 \% \mathrm{G}$, and $25 \% \mathrm{C}$. Italicized nucleotides indicate positions of the zipcode that were constant. Selection of RNAs was performed as described previously (Chao et al. 2010). The stringency of selection was increased by progressively reducing the concentration of MBP-ZBP1 KH34 in the binding reaction. In the first round of selection, MBP-ZBP1 KH34 (300 nM) was equilibrated with the library RNA pool (400 nM). In subsequent rounds of selection, the concentration of MBP-ZBP1 $\mathrm{KH} 34$ was reduced to $10 \mathrm{nM}$ (rounds 2 and 3 ) and $5 \mathrm{nM}$ (rounds 4-9), while maintaining an RNA concentration of $100 \mathrm{nM}$.

\section{NMR spectroscopy}

Two-dimensional 1H,15N HSQC and three-dimensional deuterium-decoupled, gradient sensitivity-enhanced triple-resonance experiments [ $\mathrm{HNCO}, \mathrm{HN}(\mathrm{CA}) \mathrm{CO}, \mathrm{HNCA}, \mathrm{HN}(\mathrm{CO}) \mathrm{CA}, \mathrm{HN}(\mathrm{CA}) \mathrm{CB}$, and $\mathrm{HN}(\mathrm{COCA}) \mathrm{CB}$ ) (Yamazaki et al. 1994) were acquired at $298 \mathrm{~K}$ on a Varian $600 \mathrm{MHz}$ INOVA spectrometer equipped with a triple-resonance cryogenically cooled probe, including a $z$-axis pulse field gradient coil. NMR data were processed using NMRpipe/NMRDraw (Delaglio et al. 1995) and analyzed using CCPN Analysis (Vranken et al. 2005). Chemical shifts were indirectly referenced to sodium 2,2-dimethyl-2-silanepentane5 -sulfonate (DSS), using absolute frequency ratios for the $1 \mathrm{H}$ signals (Wishart et al. 1995). Due to the low concentration of the KH34:RNA complexes $(\sim 50 \mu \mathrm{M})$, a three-dimensional HNCO experiment was acquired, and assignments for the complex were transferred from the unbound $\mathrm{KH} 34$ based on the minimal chemical shift approach using the $1 \mathrm{H}, 15 \mathrm{~N}$, and $13 \mathrm{CO}$ chemical shifts (Farmer and Venters 1996). The average chemical shift change for the backbone amide $1 \mathrm{H}$ and $15 \mathrm{~N}$ nuclei $(\Delta \delta \mathrm{av})$ for the IMP1:RNA complexes was calculated using the equation $\Delta \delta$ av $=$ $\sqrt{ }\left[(\Delta \delta \mathrm{N} / 5)^{2}+\Delta \delta \mathrm{H}^{2}\right] / 2$, where $\mathrm{N}$ represents the change in the amide nitrogen chemical shift and $\mathrm{H}$ represents the change in the amide proton chemical shift (Garrett et al. 1997).

\section{Bioinformatics}

The UCSC Genome Browser was used to query the foldUtr3 tables of the human (February 2009 assembly, GRCh37/hg19) and mouse (February 2006 assembly, NCBI36/MM8) genomes for 3' UTRs containing the nucleotide sequences CGGAC-(N1025)-(C/A)-CA-(C/U) or (C/A)-CA-(C/U)-(N10-25)-CGGAC, where $\mathrm{N}$ represents any intervening nucleotide. Genes demonstrating conservation of this sequence motif between human and mouse genomes were identified as potential RNA ligands of ZBP1 in vivo.

IPA Knowledge Base 9 (Ingenuity Systems) was used to explore the functional relationship between the proteins encoded by the 114 potential, evolutionarily conserved mRNA ligands of ZBP1 KH34. These 114 "focus genes" were analyzed for direct interactions within the 26 disease and disorder categories and 49 molecular and cellular function categories in the IPA Knowledge Base. Enrichment of focus genes to these diseases and functional categories was evaluated. The $P$-value, based on a right-tailed Fisher's exact test, considers the number of identified focus 
genes and the total number of molecules known to be associated with these categories in the IPA Knowledge Base. Significance was determined when an individual pathway reached a false discovery rate of $<0.05$.

\section{Immunoprecipitation of endogenous $Z B P 1$}

Brains were isolated from embryonic day 13 (E13) mice, rinsed with cold $1 \times$ PBS, and pelleted by centrifugation at $1000 \mathrm{~g}$ for 5 $\mathrm{min}$. Cells were resuspended in polysomal lysis buffer $10 \mathrm{mM}$ HEPES at $\mathrm{pH} 7.0,100 \mathrm{mM} \mathrm{KCl}, 5 \mathrm{mM} \mathrm{MgCl} 2,0.5 \%$ Nonidet P-40, $1 \mathrm{mM}$ DTT, $100 \mathrm{U} \mathrm{mL}^{-1}$ RNase OUT [Invitrogen], $400 \mu \mathrm{M}$ vanadyl ribonucleoside complex [New England Biolabs], $1 \times$ Complete EDTA-free protease inhibitor tablet [Roche]) and incubated for $5 \mathrm{~min}$ on ice before freezing at $-80^{\circ} \mathrm{C}$. In order to reduce background, cell lysates were incubated with protein A Dynabeads (Invitrogen) in NT2 buffer (50 mM Tris at pH 7.4, $150 \mathrm{mM} \mathrm{NaCl}$, $1 \mathrm{mM} \mathrm{MgCl}_{2}, 0.5 \%$ Nonidet P-40) for $1 \mathrm{~h}$ at $4^{\circ} \mathrm{C}$. Precleared cell lysates were added to protein A Dynabeads coated with either a polyclonal RIP-grade ZBP1 antibody (RN007P, MBL International) or a nonspecific control IgG rabbit antibody in NT2 buffer supplemented with $20 \mathrm{mM}$ EDTA, $1 \mathrm{mM}$ DTT, and $200 \mathrm{U}$ of RNase OUT and were incubated for $4 \mathrm{~h}$ at $4^{\circ} \mathrm{C}$ with end-over-end tumbling. Beads were washed six times with NT2 buffer and then incubated with $30 \mu \mathrm{g}$ of proteinase $\mathrm{K}$ for $30 \mathrm{~min}$ at $55^{\circ} \mathrm{C}$ in a Thermomixer (Eppendorf) to release immunoprecipitated mRNPs. RNA was isolated by phenol-chloroform extraction and ethanol precipitation. Precipitated RNA (200 ng for both ZBP1 and IgG pull-downs) was used to reverse-transcribe cDNA using SuperScript III reverse transcriptase (Invitrogen) with random hexamer primers. Experiments were replicated at least two times using independent RIP experiments from littermate embryos.

\section{Total RNA isolation from ZBP1-WT and ZBP1-KO embryos}

Brains were isolated from littermate wild-type and ZBP1-KO embryos (Z Katz and RH Singer in prep.) on E13, and total RNA was extracted using the RNeasy mini kit (Qiagen) as per the manufacturer's protocol. RNA (1 $\mu \mathrm{g}$ for both ZBP1-WT and ZBP1-KO) was used to reverse-transcribe cDNA using SuperScript III reverse transcriptase (Invitrogen) with random hexamer primers. Experiments were replicated three times using independent RNA isolations from littermate embryos.

\section{qPCR}

Real-time PCR amplification of cDNA was performed with POWER SYBR Green reagent (Applied Biosystems) performed on the ABI 7300 real-time PCR system. The primer sequences used for PCR amplification of target genes are included in the Supplemental Material. Threshold cycle $\left(\mathrm{C}_{\mathrm{T}}\right)$ values were automatically determined using ABI 7300 SDS software version 1.4 and analyzed using the comparative $\mathrm{C}_{\mathrm{T}}$ method as previously described (Schmittgen and Livak 2008).

\section{GFP-spinophilin 3' UTR reporter constructs}

The spinophilin 3' UTR (1-1532) and spinophilin 3' UTR $\Delta$ KH34 REs (44-1455) were cloned from embryonic mouse brain cDNA by PCR. PCR products were cloned into a pHAGE-Ubc-GFP lentiviral vector, which placed the reporter 3' UTRs directly downstream from the GFP-coding sequence. This plasmid was transfected in HEK293T cells along with the lentiviral packaging plasmids (Gag-Pol, Rev, Tat, and VSV-g) in order to generate infectious virus particles (Mostoslavsky et al. 2005). Viral particles were harvested every $24 \mathrm{~h}$ for $3 \mathrm{~d}$ after transfection and were concentrated using Lenti-X concentrator (Clonetech). Infection rates of neuronal cultures were $\geq 30 \%$ as determined by GFP fluorescence.

\section{Hippocampal neuron culture}

Mouse hippocampi were dissected from wild-type and ZBP1-KO mice and cultured on E18 as previously described (Kaech and Banker 2006). Coverslips were coated with poly D-lysine $(1.0 \mathrm{mg} /$ $\mathrm{mL})$ and then plated $(60,000-90,000$ cells per square centimeter in minimal essential medium [MEM] with fetal bovine serum [10\%] for $4 \mathrm{~h})$. Coverslips were then transferred to dishes containing defined Neurobasal (NB) medium (Gibco) supplemented with Glutamax and B-27 growth supplement (Gibco). For GFPreporter experiments, neurons were infected with recombinant lentiviral particles on day 5 in vitro (DIV5). Neurons were cultured for DIV8 (for assessment of GFP reporter mRNA) or DIV12 (for endogenous spinophilin mRNA). Prior to fixation, cells were incubated with $2 \mu \mathrm{M}$ cell-permeable blue fluorescent dye 7-amino4-chloromethylcoumarin (CMAC) (Molecular Probes). Cells were then fixed with $4 \%$ paraformaldehyde and $5 \mathrm{mM} \mathrm{MgCl}_{2}$ in $1 \times$ PBS for $20 \mathrm{~min}$ at room temperature and then washed in $1 \times$ PBS and $0.1 \mathrm{M}$ glycine to quench fixation. Cells were subsequently permeabilized with $0.5 \%$ Triton X-100 in $1 \times$ PBS, washed in $1 \times$ PBS, and stored in $70 \%$ ethanol at $4^{\circ} \mathrm{C}$.

\section{FISH}

Gene-specific oligodeoxynucleotide probes for spinophilin (10 probes) and GFP (three probes) were designed, synthesized, and labeled as described previously (Femino et al. 1998). Probes [40-mer for GFP and 50-mer for spinophilin, oligo(dT)] each contained three or four amino-modified nucleotides (amino-allyl T). The free amines were chemically coupled to cyanine 3 (Cy3) fluorescent dye (GE Healthcare) after synthesis with nearly complete $(>90 \%)$ labeling efficiency. The sequences for probes used are in the Supplemental Material.

FISH was performed as described previously (Femino et al. 1998). Stored coverslips were rehydrated with $1 \times$ PBS and incubated $1.5 \mathrm{~h}$ in prehybridization solution $150 \%$ formamide for 50 -mer probes or $40 \%$ formamide for 40 -mer probes, $2 \times$ SSC, $2 \mathrm{mg} / \mathrm{mL}$ BSA, $0.6 \mathrm{mg} \mathrm{mL}^{-1}$ E. coli tRNA, $0.6 \mathrm{mg} \mathrm{mL}^{-1}$ sheared salmon sperm DNA) at $37^{\circ} \mathrm{C}$. Probes were hybridized to the cells for $5 \mathrm{~h}$ in prehybridization solution supplemented with $15 \mathrm{ng}$ of probe mixture per coverslip. Following hybridization, the coverslips were washed twice for $30 \mathrm{~min}$ at $37^{\circ} \mathrm{C}$ with prehybridization solution and then twice for $1 \mathrm{~h}$ at room temperature in $1 \times$ PBS. After the final wash, the coverslips were mounted on slides using ProLong gold reagent (Invitrogen).

\section{Quantitative image analysis}

Images were acquired on an Olympus BX61 epifluorescence microscope with a UPlanApo $60 \times, 1.4$ numerical aperture oilimmersion objective (Olympus). An X-Cite 120 PC (EXFO) light source was used for illumination, with filter sets 31000 (DAPI, CMAC), 41001 (GFP), and SP-102v1 (Cy3) (Chroma Technology). Vertical stacks of 21 images with a $Z$-step size of $0.2 \mu \mathrm{m}$ were acquired using a CoolSNAP HQ camera (Photometrics) with a 6.4- $\mu \mathrm{m}$-pixel size CCD. MetaMorph (Molecular Devices) software platform was used for instrument control as well as image acquisition.

Three-dimensional image stacks were reduced to two-dimensional images by applying a maximum intensity projection along the $Z$-axis using ImageJ (National Institutes of Health [NIH]). We automatically located diffraction-limited fluorescence signals from individual mRNAs within dendrites using a previous 
implementation (Lionnet et al. 2011) of the two-part Gaussian mask algorithm (Matlab, Mathworks). First, the approximate position of the mRNAs in the image was determined by applying a spatial bandpass filter to the image and selecting pixels above a manually set threshold. Particles were assigned at the position of isolated high-intensity pixels. When clusters of adjacent highintensity pixels were encountered, particles were assigned to the position of the local intensity maxima within the cluster (using a 2-pixel radius). The local intensity profile around each particle position was fit to a two-dimensional Gaussian used as an approximation of the point spread function (PSF). Using a region of interest (ROI) surrounding the approximated particle position, the algorithm subtracted a local estimate of the fluorescent background from the pixel intensities. The background-corrected intensity profile was then used to determine the center and fluorescence intensity of the spot using a two-dimensional Gaussian mask algorithm (Thompson et al. 2002).

Consistent with single mRNA particles, the intensity values of the detected spots were normally distributed (Supplemental Fig. S8). Imaging was sensitive enough to detect single fluorescent probes attached to the coverglass in cell-free areas. Importantly, these single probes could easily be distinguished from the mRNA particles based on fluorescence intensity (Supplemental Fig. S8). This clear separation ensured the selectivity of the technique, as only mRNAs bound to multiple FISH probes were detected. The position of each mRNA relative to the cell body was obtained by running the detection algorithm on linearized images of individual dendrites generated by straightening the spline fit of segmented lines drawn along the contour of each dendrite using the segmented line tool in ImageJ.

Quantitative image data for spinophilin RNA localization were collected over 25 wild-type and 23 ZBP1-KO neurons. Data for poly-A mRNA FISH were collected over 10 wild-type and 11 ZBP1-KO neurons. Data for GFP reporter localization were collected over 15 neurons infected with GFP-spinophilin 3' UTR and 19 neurons infected with GFP-spinophilin 3' UTR $\Delta$ KH34 REs.

\section{Accession codes}

IMP1 KH34 backbone assignments were deposited at the Biological Magnetic Resonance Bank with accession code 17815.

\section{Acknowledgments}

This work was supported by the U.S. NIH GM84364 to R.H.S., NIH NIGMS MSTP Training Grant T32-GM007288 to V.L.P., NIH NIGMS NRSA F32GM083430 to J.A.C., NIH NIGMS RO1085130 to M.B., a Human Frontier Science Program Long-Term Fellowship to T.L., and an American Medical Association Foundation Seed Grant to V.L.P.

\section{References}

Auweter SD, Oberstrass FC, Allain FH. 2006. Sequence-specific binding of single-stranded RNA: Is there a code for recognition? Nucleic Acids Res 34: 4943-4959.

Backe PH, Messias AC, Ravelli RB, Sattler M, Cusack S. 2005. $\mathrm{X}$-ray crystallographic and NMR studies of the third $\mathrm{KH}$ domain of hnRNP K in complex with single-stranded nucleic acids. Structure 13: 1055-1067.

Chao JA, Patskovsky Y, Patel V, Levy M, Almo SC, Singer RH. 2010. ZBP1 recognition of $\beta$-actin zipcode induces RNA looping. Genes Dev 24: 148-158.

Delaglio F, Grzesiek S, Vuister GW, Zhu G, Pfeifer J, Bax A. 1995. NMRPipe: A multidimensional spectral processing system based on UNIX pipes. J Biol NMR 6: 277-293.
Du Z, Lee JK, Fenn S, Tjhen R, Stroud RM, James TL. 2007. X-ray crystallographic and NMR studies of protein-protein and protein-nucleic acid interactions involving the KH domains from human poly(C)-binding protein-2. RNA 13: 1043-1051.

Du Z, Fenn S, Tjhen R, James TL. 2008. Structure of a construct of a human poly(C)-binding protein containing the first and second $\mathrm{KH}$ domains reveals insights into its regulatory mechanisms. J Biol Chem 283: 28757-28766.

Eom T, Antar LN, Singer RH, Bassell GJ. 2003. Localization of a $\beta$-actin messenger ribonucleoprotein complex with zipcodebinding protein modulates the density of dendritic filopodia and filopodial synapses. J Neurosci 23: 10433-10444.

Farina KL, Huttelmaier S, Musunuru K, Darnell R, Singer RH. 2003. Two ZBP1 KH domains facilitate $\beta$-actin mRNA localization, granule formation, and cytoskeletal attachment. J Cell Biol 160: 77-87.

Farmer BT 2nd, Venters RA. 1996. Assignment of aliphatic sidechain $1 \mathrm{HN} / 15 \mathrm{~N}$ resonances in perdeuterated proteins. J Biol NMR 7: 59-71.

Femino AM, Fay FS, Fogarty K, Singer RH. 1998. Visualization of single RNA transcripts in situ. Science 280: 585-590.

Garrett DS, Seok YJ, Liao DI, Peterkofsky A, Gronenborn AM, Clore GM. 1997. Solution structure of the $30 \mathrm{kDa}$ N-terminal domain of enzyme I of the Escherichia coli phosphoenolpyruvate: sugar phosphotransferase system by multidimensional NMR. Biochemistry 36: 2517-2530.

Granneman S, Kudla G, Petfalski E, Tollervey D. 2009. Identification of protein binding sites on U3 snoRNA and prerRNA by UV cross-linking and high-throughput analysis of cDNAs. Proc Natl Acad Sci 106: 9613-9618.

Hafner M, Landthaler M, Burger L, Khorshid M, Hausser J, Berninger P, Rothballer A, Ascano M, Jungkamp AC, Munschauer M, et al. 2010. Transcriptome-wide identification of RNA-binding protein and microRNA target sites by PAR-CLIP. Cell 141: 129-141.

Hansen TV, Hammer NA, Nielsen J, Madsen M, Dalbaeck C, Wewer UM, Christiansen J, Nielsen FC. 2004. Dwarfism and impaired gut development in insulin-like growth factor II mRNA-binding protein 1-deficient mice. Mol Cell Biol 24: 4448-4464.

Holt CE, Bullock SL. 2009. Subcellular mRNA localization in animal cells and why it matters. Science 326: 1212-1216.

Huttelmaier S, Zenklusen D, Lederer M, Dictenberg J, Lorenz M, Meng X, Bassell GJ, Condeelis J, Singer RH. 2005. Spatial regulation of $\beta$-actin translation by Src-dependent phosphorylation of ZBP1. Nature 438: 512-515.

Jonson L, Vikesaa J, Krogh A, Nielsen LK, Hansen T, Borup R, Johnsen AH, Christiansen J, Nielsen FC. 2007. Molecular composition of IMP1 ribonucleoprotein granules. Mol Cell Proteomics 6: 798-811.

Kaech S, Banker G. 2006. Culturing hippocampal neurons. Nat Protoc 1: 2406-2415.

Keene JD, Tenenbaum SA. 2002. Eukaryotic mRNPs may represent posttranscriptional operons. Mol Cell 9: 1161-1167.

Keene JD, Komisarow JM, Friedersdorf MB. 2006. RIP-Chip: The isolation and identification of mRNAs, microRNAs and protein components of ribonucleoprotein complexes from cell extracts. Nat Protoc 1: 302-307.

Kim HS, Wilce MC, Yoga YM, Pendini NR, Gunzburg MJ, Cowieson NP, Wilson GM, Williams BR, Gorospe M, Wilce JA. 2011. Different modes of interaction by TIAR and HuR with target RNA and DNA. Nucleic Acids Res 39: 11171130.

Kislauskis EH, Zhu X, Singer RH. 1994. Sequences responsible for intracellular localization of $\beta$-actin messenger RNA also affect cell phenotype. I Cell Biol 127: 441-451. 
Kwon S, Abramson T, Munro TP, John CM, Kohrmann M, Schnapp BJ. 2002. UUCAC- and vera-dependent localization of VegT RNA in Xenopus oocytes. Curr Biol 12: 558564.

Lamichhane R, Daubner GM, Thomas-Crusells J, Auweter SD, Manatschal C, Austin KS, Valniuk O, Allain FH, Rueda D. 2010. RNA looping by PTB: Evidence using FRET and NMR spectroscopy for a role in splicing repression. Proc Natl Acad Sci 107: 4105-4110.

Lawrence JB, Singer RH. 1986. Intracellular localization of messenger RNAs for cytoskeletal proteins. Cell 45: 407-415.

Lewis HA, Musunuru K, Jensen KB, Edo C, Chen H, Darnell RB, Burley SK. 2000. Sequence-specific RNA binding by a Nova $\mathrm{KH}$ domain: Implications for paraneoplastic disease and the fragile X syndrome. Cell 100: 323-332.

Licatalosi DD, Mele A, Fak JJ, Ule J, Kayikci M, Chi SW, Clark TA, Schweitzer AC, Blume JE, Wang X, et al. 2008. HITSCLIP yields genome-wide insights into brain alternative RNA processing. Nature 456: 464-469.

Lionnet T, Czaplinski K, Darzacq X, Shav-Tal Y, Wells AL, Chao JA, Park HY, de Turris V, Lopez-Jones M, Singer RH. 2011. A transgenic mouse for in vivo detection of endogenous labeled mRNA. Nat Methods 8: 165-170.

Lunde BM, Moore C, Varani G. 2007. RNA-binding proteins: Modular design for efficient function. Nat Rev Mol Cell Biol 8: 479-490.

Mackereth CD, Madl T, Bonnal S, Simon B, Zanier K, Gasch A, Rybin V, Valcarcel J, Sattler M. 2011. Multi-domain conformational selection underlies pre-mRNA splicing regulation by U2AF. Nature 475: 408-411.

Martin KC, Ephrussi A. 2009. mRNA localization: Gene expression in the spatial dimension. Cell 136: 719-730.

Mostoslavsky G, Kotton DN, Fabian AJ, Gray JT, Lee JS, Mulligan RC. 2005. Efficiency of transduction of highly purified murine hematopoietic stem cells by lentiviral and oncoretroviral vectors under conditions of minimal in vitro manipulation. Mol Ther 11: 932-940.

Munro TP, Kwon S, Schnapp BJ, St Johnston D. 2006. A repeated IMP-binding motif controls oskar mRNA translation and anchoring independently of Drosophila melanogaster IMP. J Cell Biol 172: 577-588.

Musco G, Kharrat A, Stier G, Fraternali F, Gibson TJ, Nilges M, Pastore A. 1997. The solution structure of the first $\mathrm{KH}$ domain of FMR1, the protein responsible for the fragile $\mathrm{X}$ syndrome. Nat Struct Biol 4: 712-716.

Nielsen J, Christiansen J, Lykke-Andersen J, Johnsen AH, Wewer UM, Nielsen FC. 1999. A family of insulin-like growth factor II mRNA-binding proteins represses translation in late development. Mol Cell Biol 19: 1262-1270.

Perycz M, Urbanska AS, Krawczyk PS, Parobczak K, Jaworski J. 2011. Zipcode binding protein 1 regulates the development of dendritic arbors in hippocampal neurons. I Neurosci 31: 5271-5285.

Ray D, Kazan H, Chan ET, Pena Castillo L, Chaudhry S, Talukder S, Blencowe BJ, Morris Q, Hughes TR. 2009. Rapid and systematic analysis of the RNA recognition specificities of RNA-binding proteins. Nat Biotechnol 27: 667-670.

Ross AF, Oleynikov Y, Kislauskis EH, Taneja KL, Singer RH. 1997. Characterization of a $\beta$-actin mRNA zipcode-binding protein. Mol Cell Biol 17: 2158-2165.

Schmittgen TD, Livak KJ. 2008. Analyzing real-time PCR data by the comparative C(T) method. Nat Protoc 3: 1101-1108.

Shestakova EA, Singer RH, Condeelis J. 2001. The physiological significance of $\beta$-actin mRNA localization in determining cell polarity and directional motility. Proc Natl Acad Sci 98: 7045-7050.
Shimogori T, Lee DA, Miranda-Angulo A, Yang Y, Wang H, Jiang L, Yoshida AC, Kataoka A, Mashiko H, Avetisyan M, et al. 2010. A genomic atlas of mouse hypothalamic development. Nat Neurosci 13: 767-775.

Thompson RE, Larson DR, Webb WW. 2002. Precise nanometer localization analysis for individual fluorescent probes. Biophys J 82: 2775-2783.

Tiruchinapalli DM, Oleynikov Y, Kelic S, Shenoy SM, Hartley A, Stanton PK, Singer RH, Bassell GJ. 2003. Activity-dependent trafficking and dynamic localization of zipcode binding protein 1 and $\beta$-actin mRNA in dendrites and spines of hippocampal neurons. I Neurosci 23: 3251-3261.

Ule I, Stefani G, Mele A, Ruggiu M, Wang X, Taneri B, Gaasterland T, Blencowe BJ, Darnell RB. 2006. An RNA map predicting Nova-dependent splicing regulation. Nature 444: 580-586.

Vikesaa J, Hansen TV, Jonson L, Borup R, Wewer UM, Christiansen J, Nielsen FC. 2006. RNA-binding IMPs promote cell adhesion and invadopodia formation. EMBO J 25: 1456-1468.

Vranken WF, Boucher W, Stevens TJ, Fogh RH, Pajon A, Llinas M, Ulrich EL, Markley JL, Ionides J, Laue ED. 2005. The CCPN data model for NMR spectroscopy: Development of a software pipeline. Proteins 59: 687-696.

Wishart DS, Bigam CG, Yao J, Abildgaard F, Dyson HJ, Oldfield E, Markley JL, Sykes BD. 1995. 1H, 13C and 15N chemical shift referencing in biomolecular NMR. I Biol NMR 6: 135140.

Yamazaki T, Nicholson LK, Torchia DA, Stahl SJ, Kaufman JD, Wingfield PT, Domaille PJ, Campbell-Burk S. 1994. Secondary structure and signal assignments of human-immunodeficiency-virus-1 protease complexed to a novel, structurebased inhibitor. Eur J Biochem 219: 707-712.

Yaniv K, Yisraeli JK. 2002. The involvement of a conserved family of RNA binding proteins in embryonic development and carcinogenesis. Gene 287: 49-54.

Yao J, Sasaki Y, Wen Z, Bassell GJ, Zheng JQ. 2006. An essential role for $\beta$-actin mRNA localization and translation in $\mathrm{Ca}^{2+}$. dependent growth cone guidance. Nat Neurosci 9: 1265-1273.

Yeo GW, Coufal NG, Liang TY, Peng GE, Fu XD, Gage FH. 2009. An RNA code for the FOX2 splicing regulator revealed by mapping RNA-protein interactions in stem cells. Nat Struct Mol Biol 16: 130-137.

Yisraeli JK. 2005. VICKZ proteins: A multi-talented family of regulatory RNA-binding proteins. Biol Cell 97: 87-96.

Zhang HL, Singer RH, Bassell GJ. 1999. Neurotrophin regulation of $\beta$-actin mRNA and protein localization within growth cones. J Cell Biol 147: 59-70.

Zhang HL, Eom T, Oleynikov Y, Shenoy SM, Liebelt DA, Dictenberg JB, Singer RH, Bassell GJ. 2001. Neurotrophininduced transport of a $\beta$-actin mRNP complex increases $\beta$-actin levels and stimulates growth cone motility. Neuron 31: 261-275.

Zhang C, Frias MA, Mele A, Ruggiu M, Eom T, Marney CB, Wang H, Licatalosi DD, Fak JJ, Darnell RB. 2010. Integrative modeling defines the Nova splicing-regulatory network and its combinatorial controls. Science 329: 439-443.

Zhong J, Zhang T, Bloch LM. 2006. Dendritic mRNAs encode diversified functionalities in hippocampal pyramidal neurons. BMC Neurosci 7: 17. doi: 10.1186/1471-2202-7-17. 


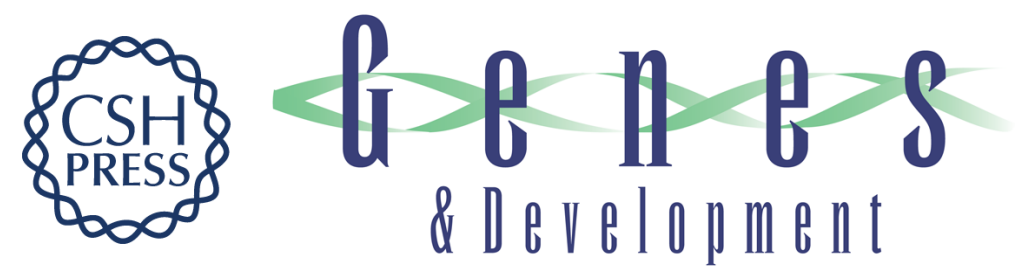

\section{Spatial arrangement of an RNA zipcode identifies mRNAs under post-transcriptional control}

Vivek L. Patel, Somdeb Mitra, Richard Harris, et al.

Genes Dev. 2012, 26:

Access the most recent version at doi:10.1101/gad.177428.111

\section{Supplemental http://genesdev.cshlp.org/content/suppl/2012/01/03/26.1.43.DC1 Material}

Related Content

References

\section{License}

Email Alerting

Service
This article cites 56 articles, 21 of which can be accessed free at:

http://genesdev.cshlp.org/content/26/1/43.full.html\#ref-list-1

Articles cited in:

http://genesdev.cshlp.org/content/26/1/43.full.html\#related-urls

A zipcode unzipped

Michael Doyle and Michael A. Kiebler

Genes Dev. January, 2012 26: 110-113

Receive free email alerts when new articles cite this article - sign up in the box at the top right corner of the article or click here.

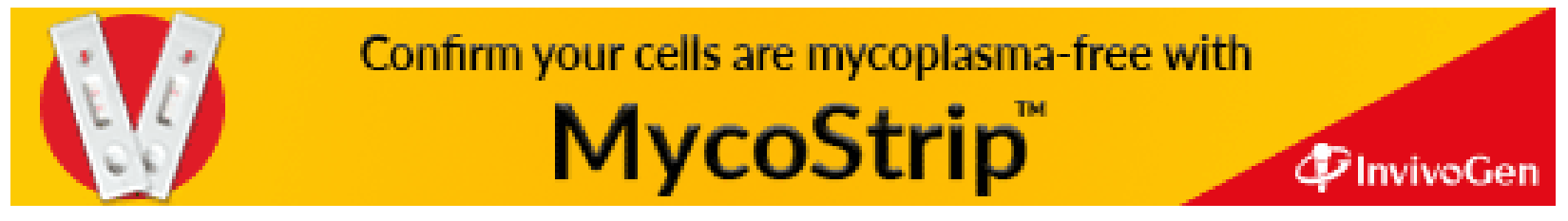

